\title{
Editorial
}

\section{Re-establishing trust in financial services}

\section{A WELL-WORN THEME}

Trust is a sine qua non in brand management, a 'hygiene factor' that brand practitioners look to go far beyond in creating compelling stakeholder relationships - important, then, but not exactly new. Readers will be forgiven if they feel that the issue of trust, particularly in the context of financial services, is perhaps a threadbare theme.

Nevertheless, in the UK, the issue of trust is firmly back on the agenda: with respect to politicians and the political system, in corporations generally and specifically in financial services institutions. Bearing in mind the centrality of the financial services industry to the UK economy and to society more broadly, it should come as no surprise that this area is under an especially harsh spotlight. The figures speak for themselves:

- Ninety-five per cent of UK adults have current or deposit accounts and 60 per cent have credit or charge cards.

- There are 10,000 financial institutions operating in the UK, excluding financial advisers and intermediaries.

- The financial services sector contributes around $\mathcal{E}^{13 \mathrm{~b} n}$ net to the UK's current account.

- The total value of UK pension funds is equivalent to two-thirds of the UK's annual GDP. (Source: Richard Meddings, Executive Director, Standard Chartered Bank.)
Consumer protection and confidence are surely therefore at the very top of the agenda for both the industry and for the Government and the regulators. Yet, in 2002, the financial services ombudsman received 50,000 complaints about the mis-selling of endowment policies. The Equitable Life story has deeply affected the man in the street and his perceptions of the industry, while the scandal surrounding split-level investment trusts begs the inevitable question 'how has this been allowed to happen?'

People have had their confidence in the industry severely shaken and this is a real issue for a society facing a crisis in pension provision and an increasing tax burden. It is estimated that the basic state pension provision will be worth just 9 per cent of average earnings by $2050 ; 75$ per cent of occupational pension schemes are now closed to new members; and research by the Association of British Insurers suggests that some 8 million people in work are not saving at all for retirement, with a further 2 million not saving enough (Source: Richard Lambert, MPC committee member and former editor of the Financial Times).

\section{TRUST AND REGULATION}

So, where does responsibility for this situation lie on the spectrum between government regulation and institutions' responsibility to inspire trust? 
Templeton College, Oxford, recently hosted a symposium entitled 'Ethical Frameworks for Financial Services', in which participants explored the issue of trust in financial services institutions. The starting point had been the publication of discussion paper DP18 of the same name by the UK's Financial Services Authority, in which the limits of regulation had been acknowledged. As Michael Earl, the Dean of Templeton, concluded in his foreword to the day, 'trust, therefore, is the key'.

\section{REDEFINING 'TRUST'}

But what precisely do we mean by 'trust'? As Baroness Onora O'Neill, Principal of Newnham College, Cambridge, noted during the 'Ethical Frameworks for Financial Services' symposium: 'if we conceive of trust simply as a matter of (blind) acceptance or deference, and similar attitudes, we could reasonably conclude that trust should play little part in the public life of a mature democracy, or in its institutional or professional life'.

Citizens and consumers have moved on from doffing their respective caps to doctors, lawyers, policemen, politicians, civil servants and bank managers. Society now bristles with suspicion and cynicism. How have financial services institutions responded to this changed agenda? How have they - and others — sought to win back the respect of key constituencies?

The prevailing reaction has been to think of accountability and transparency as the natural way forward, by which is meant target setting and information provision. But, as Professor O'Neill goes on to point out, 'the arguments for embracing this specific conception of the way in which managers should be held to account are astonishingly sparse ... [and] ... shovelling facts and figures onto websites is not usually a good way of communicating'.

What, then, would a more intelligent conception of trust look like? According to Professor O'Neill 'it would start with the thought that ... both placing and refusing trust are based on judgement either of truth claims or commitments to action'. Within the financial services area, this thought is supported by evidence from a survey by Circus in 2002 - 'Does Brand Alignment Lead to Customer Satisfaction and Employee Satisfaction?' - that suggested that whether a provider 'delivers what it says it will' is two to three times more important than any other factor in driving customer satisfaction.

This is the crux of the matter. What is the role, then, of marketers in this conception of trust?

\section{TRUST AND 'BRAND'}

Such a definition should be of particular interest to the marketing profession. It explicitly recognises the central responsibility of marketing in generating and retaining trust, perhaps most succinctly expressed in the definition of a brand as 'a promise that must be kept'. The issue, of course, is the limit of marketing's current influence in organisations - marketing directors are seldom in charge of all of the touch points across the entire stakeholder community, as they would need to be in order to fulfil the demands of the definition. Chief executives - who could be in charge of all of the 
touch points - tend to delegate delivery to functional heads, which makes for fragmentation and dissonant stakeholder experiences. This in turn makes for erosion of trust, actively undermining marketing's good work in defining, communicating and delivering against 'truth claims'.

Some change in attitudes does seem to be taking place. Certainly, an increasing number of organisations in both the commercial and not-for-profit sectors have acknowledged that the best foundation is a simple, compelling idea that encapsulates what the organisation stands for, and that this should guide everything it (claims and) does. Such a conceptual model provides the most efficient framework for authentic and motivating delivery that builds trust and loyalty.

Enlightened chief executives have recognised that any dissonance between such a core idea and the stakeholder experience at any touch point will damage the reputation of the organisation, and thus its potential to engender trust (as well as affecting, for commercial organisations, market capitalisation). Whether the organisation and its stakeholders wish to use the word 'brand' or not, the marketing fraternity would recognise the notion.

\section{THE ISSUE WITH 'MISSION, VISION AND VALUES'}

For many organisations, however, this sort of programme - particularly when driven by non-marketing professionals - rapidly becomes a standard, uninspiring cataloguing designed not to put noses out of joint - lowest common denominator, rather than highest common factor. The holy trinity of mission, vision and values can be transplanted all too easily between organisations that in reality have very little in common.

The intention is a worthy one. As Richard Lambert, MPC committee member and former editor of the Financial Times, insists: it is essential 'for companies to pay more attention to developing a cohesive corporate culture and to building a corporate ethic'. Similarly, Richard Wright of the FSA notes in the context of the debate around trust that 'controls are indissolubly linked with culture'. There has been much talk of 're-institutionalising' the appropriate values.

But the very worthiness of the intention can be directly responsible for poor execution. In industries plagued by concerns around safety, security and/or trustworthiness, value sets scarcely rise above the generic. Research by de Chernatony and Harris $^{1}$ among 13 financial services providers suggests that providers are failing miserably to go beyond the merely generic. While this is arguably less of an issue for monopoly sectors, such as rail infrastructure or the regional water companies, it is of critical importance for the intensely competitive financial services industry.

It is not enough for mission, vision and values merely to cover the basics, important as they are. The project must be far more ambitious. Mission, vision and values must resonate for all an organisation's internal and external stakeholders. For a financial services institution, they have to incorporate the critically important 'hygiene factors', encapsulate its authentic particularities and create distinctiveness from competitor organisations - 
there should be a role for all components built into the model.

In terms of genuine authenticity and distinctiveness, the research by de Chernatony and Harris demonstrate a pattern of generic, rather than distinctive, values. The paper concludes that 'the most frequently-occurring ... were values that consumers would expect financial services brands to demonstrate, so would result in dissatisfaction if contravened, but their mere presence would be unlikely to result in satisfaction'.

Furthermore, in terms of internal alignment, the research went on to reveal 'a worrying lack of correspondence (between managers' perceptions of the values and) ... the "official" values'. This lack of common understanding and buy-in in turn strongly implies an inconsistency of delivery that would undermine stakeholder confidence in the providers.

\section{A WINDOW OF OPPORTUNITY}

A more intelligent definition of trust demands root-and-branch alignment behind and delivery of an authentic, compelling organisational idea. Happily for marketing directors, it also offers them the opportunity to place themselves at the very heart of the debate about trust and, therefore, organisational strategy.

\section{Jonathan Hall Editorial Board}

\section{References}

(1) de Chernatony, L. and Harris, F. (2000) 'The Challenge of Financial Services Branding: Majoring on Category or Brand Values?', Open University Business School, Open University, UK. 